\title{
EFFECT OF PRIMING VOLUME ON SERUM CATECHOLAMINES DURING CARDIOPULMONARY BYPASS
}

\author{
Kanteerava Balasaraswathi, Silas N. Glisson, Adel A. El-Etr and Challapalli Azad
}

ABSTRACT

Several theories have been proposed to explain the transient hypotension which occurs upon the initiation of cardiopulmonary bypass. The present study investigated the possibility that addition of the lactated Ringer's solution pump priming volume to the circulation causes dilution of circulating catecholamines leading to the hypotension. Circulating epinephrine and norepinephrine levels were measured during cardiopulmonary bypass in patients anaesthetized with halothane. The results demonstrate dilution of circulating catecholamines at the start of bypass in conjunction with the observed hypotension. During the bypass period, mean blood pressure gradually recovered to normotensive levels even though circulating catecholamine levels remained significantly lowered, indicating a mechanism for the recovery of blood pressure which is not sympathoadrenal. The results obtained from this study demonstrate a temporal relationship between catecholamine dilution by the pump priming volume and the observed hypotension. Whether catecholamine dilution is the sole factor causing the hypotension remains to be determined.

AN IMMEDIATE transient hypotensive response following initiation of extracorporeal circulation is a common occurrence. Various theories have been suggested to explain the cause of the hypotension. Amongst them, most important are: (1) marked reflex vasodilatation of both resistance and capacitance vessels during the initial period of partial bypass, thought to be caused by intense triggering activity of the baroreceptor system due to pulse generation by the still beating heart and the constant infusion of fluid into the aorta from the arterial line; ${ }^{1}$ (2) alteration in the baroreceptor perception due to change in the pattern of blood flow from pulsatile to nonpulsatile type $;^{2}$ (3) decreased blood viscosity due to haemodilution; ${ }^{3}$ and (4) decreased concentration of circulating catecholamines due to plasma dilution by the extracorporeal priming volume, which is of primary interest to the authors, and is the focus of this report. This study measured the extent of extracorporeal dilution of circulating catecholamines in patients anaesthetized with halothane while undergoing aortocoronary bypass operations and assessed its role in causing the hypotensive response observed upon initiation of extracorporeal circulation.

Kanteerava Balasaraswathi, M.D., Assistant Professor; Silas N. Glisson. Ph.D., Associate Professor; Adel A. El-Etr, M.D., Professor \& Chairman; Challapalli Azad, M.D., Clinical Instructor. Department of Anesthesiology, Loyola University Stritch School of Medicine, 2160 South Firsi Avenue, Maywood, IIlinois, 60153, U.S.A., and Hines Veterans Administration Hospital, Hines, Illinois, 60141, U.S.A.

Correspondence to: Silas N. Glisson, Ph.D.

\section{Patients and Methods}

Twenty consenting adult patients of A.S.A. physical status 3 , undergoing aortocoronary bypass, were selected for the study. The patients were premedicated with $0.1 \mathrm{mg} \cdot \mathrm{kg}^{-1}$ of morphine one hour before operation. Preoperative preparation of the patients included two peripheral intravenous lines, radial artery cannulation and introduction of a central venous cannula through the right internal jugular vein. Patients were well oxygenated before induction of anaesthesia. Anaesthesia was induced with incremental doses of thiopentone (range $4-5 \mathrm{mg} \cdot \mathrm{kg}^{-1}$ ) and muscle relaxation achieved with pancuronium, $120 \mu \mathrm{g} \cdot \mathrm{kg}^{-1}$. Patients were ventilated by mask with a mixture of 50:50 oxygen and nitrous oxide. Tracheal intubation was done 3 to 4 minutes after spraying the vocal cords and trachea with $4 \mathrm{ml}$ of lidocaine four per cent. Anaesthesia was maintained with halothane, the concentration of which ranged from 0.25 to 1.5 per cent as needed. The halothane was discontinued just before the heart was defibrillated. All patients were ventilated mechanically to keep the $\mathrm{Pa}_{\mathrm{CO}_{2}}$ level at 4.66 to $5.32 \mathrm{kPa}$ (35-40 torr).

The extracorporeal system was primed with Iwo litres of lactated Ringer's solution, $50 \mathrm{ml}$ of 50 per cent glucose and $50 \mathrm{mmol}$ of sodium bicarbonate. Bypass flows were maintained at 40$-70 \mathrm{ml} / \mathrm{kg} \cdot \mathrm{min}^{-1}$. All the patients were cooled to $28^{\circ} \mathrm{C}$. No catecholamine or other inotropic agent was given during the study.

Serum epinephrine and norepinephrine were

Canad. Anaesth. Soc. J., vol. 27, no. 2, March 1980 
TABLE I

Blood Pressure Change With Cardiopulmonary Bypass

\begin{tabular}{|c|c|c|c|c|c|}
\hline & Pre & $2 \min$ & $8 \mathrm{~min}$ & Late & Post \\
\hline \multicolumn{6}{|c|}{ HaLothane } \\
\hline $\begin{array}{l}\text { Mean Blood Pressurc } \\
\text { kPa (Torr) }\end{array}$ & $11.17(84)$ & $7.71^{*}(58)$ & $8.51^{*}(64)$ & $10.37 *(78)$ & $9.84^{*}(74)$ \\
\hline 土S.E.M. & $0.48(3.6)$ & $0.57(4.3)$ & $0.44(3.3)$ & $0.45(3.4)$ & $0.29(2.2)$ \\
\hline
\end{tabular}

*Significantly different from pre-cardiopulmonary bypass, $\mathrm{p}<0.001$.

measured by fluorometric analysis of arterial blood samples as previously described. ${ }^{4}$ The blood samples were drawn at the following intervals immediately after the mean blood pressure was recorded: (1) pre-bypass, (2) two minutes after partial bypass, (3) eight minutes after bypass, and (4) before termination of cardiopulmonary bypass (LATE). Post-bypass blood pressures were taken 30 minutes after termination of cardiopulmonary bypass.

Statistical analysis of the data was done using the paired and non-paired Students t-test. A probability less than 0.05 was considered to indicate a significant difference between the test pairs.

\section{Results}

With halothane anaesthesia, initiation of cardiopulmonary bypass was associated with an

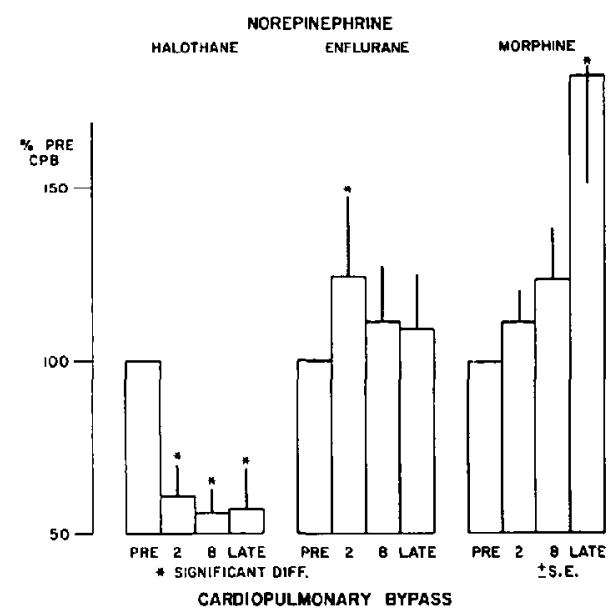

Figure 1 Comparison of mean serum norepinephrine levels during cardiopulmonary bypass with various anaesthetics. The number of patients per anaesthetic ranged from 13 to 20 . An asterisk indicates $p<0.05$ significant difference from the prebypass level using Students paired t-test.

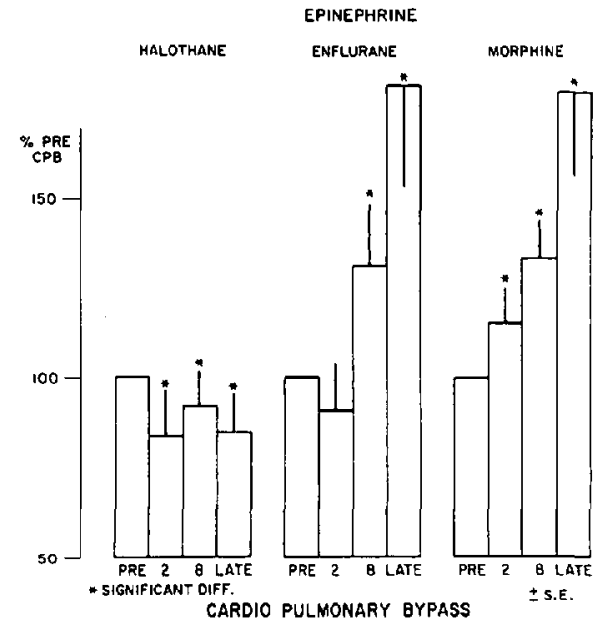

Figure 2 Comparison of mean serum epinephrine levels during cardiopulmonary bypass with various anaesthetics. Patient numbers and " $p$ " values as in Figure 1.

immediate significant fall in mean arterial blood pressure (Table 1). The duration of the hypotension was brief, and was followed by a gradual recovery of the blood pressure, although complete recovery to the prebypass level did not occur during bypass.

Circulating epinephrine and norepinephrine levels were found to be significantly lowered two minutes after initiation of cardiopulmonary bypass compared to prebypass levels. The levels remained lowered throughout the entire period of bypass (Figures 1 and 2). Serum epinephrine decreased from a pre-bypass mean ( \pm S.E.M.) level of $1560 \pm 150 \mathrm{ng} / \mathrm{l}$ to $1320 \pm 150 \mathrm{ng} / \mathrm{l}$ late in the bypass. Serum norepinephrine level decreased from $950 \pm 200 \mathrm{ng} / \mathrm{l}$ prebypass to $640 \pm 110$ late in the bypass.

An additional analysis was carried out on the halothane catecholamine data out to determine the dilutionary effect on circulating catecholamine levels resulting from the addition of two litres of pump prime solution containing no 
TABLE II

Catecholamine Output During Cardiopulmonary Bypass

\begin{tabular}{|c|c|c|c|c|c|}
\hline \multicolumn{6}{|c|}{ Halothane } \\
\hline & $\begin{array}{l}\text { Total circ. } \\
\text { ng pre-CPB }\end{array}$ & $\begin{array}{l}\text { Post dilution ( } 58 \% \text { ) } \\
\text { ng needed to add }\end{array}$ & & $\begin{array}{c}\text { Total } \\
\text { ng added }\end{array}$ & $\begin{array}{l}\text { Excess or } \\
\text { deficit ng }\end{array}$ \\
\hline $\mathrm{NE}$ & 2608 & 1513 & $\begin{array}{l}2 \text { min } \\
8 \text { min } \\
\text { Late }\end{array}$ & $\begin{array}{r}841 \\
-145 \\
+17\end{array}$ & $\begin{array}{l}-672 \\
-817 \\
-800\end{array}$ \\
\hline EPI & 5742 & 3330 & $\begin{array}{l}2 \text { min } \\
8 \text { min } \\
\text { Late }\end{array}$ & $\begin{array}{r}1323 \\
1349 \\
-1195\end{array}$ & $\begin{array}{r}-2007 \\
-658 \\
-1853\end{array}$ \\
\hline
\end{tabular}

TABLE III

Catecholamine Output During Cardopulmonary Bypass

\begin{tabular}{|c|c|c|c|c|c|}
\hline & $\begin{array}{c}\text { Total circ. } \\
\text { ng pre-CPB }\end{array}$ & $\begin{array}{l}\text { MORPH } \\
\text { Post dilution (60\%) } \\
\text { ng needed to add }\end{array}$ & & $\begin{array}{c}\text { Total } \\
\text { ng added }\end{array}$ & $\begin{array}{l}\text { Excess or } \\
\text { deficit ng }\end{array}$ \\
\hline $\mathrm{NE}$ & 4091 & 2411 & $\begin{array}{l}2 \text { min } \\
8 \text { min } \\
\text { Late }\end{array}$ & $\begin{array}{l}1738 \\
1348 \\
3858\end{array}$ & $\begin{array}{r}-673 \\
+675 \\
+4533\end{array}$ \\
\hline \multirow[t]{3}{*}{ EPI } & 3920 & 2352 & $\begin{array}{l}2 \text { min } \\
8 \text { min } \\
\text { Late }\end{array}$ & $\begin{array}{l}3421 \\
1388 \\
3738\end{array}$ & $\begin{array}{l}+1069 \\
+2457 \\
+6195\end{array}$ \\
\hline & \multicolumn{5}{|c|}{ ENFLURANE } \\
\hline & $\begin{array}{l}\text { Total circ. } \\
\text { ng pre-CPB }\end{array}$ & $\begin{array}{l}\text { Post dilution ( } 61 \% \text { ) } \\
\text { ng needed to add }\end{array}$ & & $\begin{array}{c}\text { Total } \\
\text { ng added }\end{array}$ & $\begin{array}{l}\text { Excess or } \\
\text { deficit ng }\end{array}$ \\
\hline $\mathrm{NE}$ & 4009 & 2446 & $\begin{array}{l}2 \text { min } \\
8 \text { min } \\
\text { Late }\end{array}$ & $\begin{array}{r}4248 \\
-734 \\
+196\end{array}$ & $\begin{array}{l}+1802 \\
+1068 \\
+1264\end{array}$ \\
\hline EPI & 3110 & 1897 & $\begin{array}{l}2 \text { min } \\
8 \text { min } \\
\text { Late }\end{array}$ & $\begin{array}{l}1403 \\
2418 \\
2635\end{array}$ & $\begin{array}{r}-494 \\
+1924 \\
+4559\end{array}$ \\
\hline
\end{tabular}

catecholamine to the circulating volume at the start of bypass. For the analysis, calculated patient plasma volumes $(70 \mathrm{ml} / \mathrm{kg} \times 0.62$ plasma fraction) and the measured plasma epinephrine and norepinephrine levels were used to calculate the nanogram amounts of each catecholamine that must be added to the circulation, following the two litre plasma dilution, to return the catecholamines to the predilutional circulating level.

Norepinephrine $1513 \mathrm{ng}$ and epinephrine $3330 \mathrm{ng}$ were calculated as the total amount of each catecholamine necessary to be added to the circulation to correct for the plasma catecholamine dilution by the pump prime solution (Table II). The computed results show that, over the course of the bypass, neither catecholamine was added to the circulation in sufficient amounts to make up for the dilutional effect of the priming solution. In some periods catecholamine lost to metabolism and excretion (indicated by a minus value) exceeded that which was added. For norepinephrine, only 47 per cent of the total amount required was added to the circulation during the entire period of cardiopulmonary bypass, and for epinephrine, only 44 per cent of that required was added.

To determine if the same catecholamine dilutionary changes occur with other anaesthetics, the analysis was applied to catecholamine results obtained when morphine and enflurane were used as the anaesthetics. ${ }^{4.5}$ Results of the analysis shown in Table III indicate that the percent plasma dilution in the morphine and enflurane groups was comparable to the halothane group. Likewise, the amounts of norepinephrine and epinephrine needed to correct for the pump prime dilution in these two anaesthetic groups were similar in magnitude to the halothane group. What differs from the halothane results is the 
finding that the calculated dilutional deficit of circulating norepinephrine and epinephrine was corrected within two to eight minutes after the initiation of cariopulmonary bypass in both the morphine and enflurane groups. Further, with morphine and enflurane, but not with halothane, the total amount of norepinephrine and epinephrine added to the plasma late in the bypass was found to be in excess of the amount necessary to bring the circulating epinephrine and norepinephrine to prebypass levels.

\section{Discussion}

Onset of cardiopulmonary bypass is a particularly hazardous period. Transient hypotension occurs invariably at the onset of bypass. If prolonged, this hypotension may lead to neurological, renal or cardiac damage due to decreased perfusion of these vital organs. ${ }^{6.7}$ To avoid hypotension, slow initiation of cardiopulmonary bypass, an increase of perfusion flow and/or addition of vasopressors have been recommended. ${ }^{1,6}$

Our study has provided information on the cause of transient hypotension observed at the anset of cardiopulmonary bypass. The results demonstrate a temporal relationship between lowered circulating catecholamines and the observed hypotension. Patients anaesthetized with halothane showed marked hypotension with a concomitant decrease in serum epinephrine and norepinephrine, as the blood was diluted with the priming fluid. Although the blood pressure gradually returned to the prebypass level, sustained lower levels of circulating epinephrine and norepinephrine were observed. This is in direct agreement with other investigators who have shown a depressant effect of halothane on the sympathoadrenal system. ${ }^{8,9}$ The finding that normotension (prebypass level) was achieved late in the bypass period despite low circulating catecholamines suggests that other antihypotensive reflex mechanisms are involved, such as the renin-angiotension mechanism which has been shown to be active during periods of lowered blood pressure. ${ }^{10}$ Although, in the presence of significant sympathoadrenal stimulation due to hypotension the renin-angiotension response is reported to be small or absent. "In light of the diminished sympathoadrenal response measured in this study, it is reasonable to assume that the renin-angiotension mechanism was involved in the observed recovery of blood pressure.
Results previously reported by ourselves 4.5 and others ${ }^{8,11-15}$ have shown that when morphine or enflurane are employed as main anaesthetic agents transient hypotension occurs at the onset of extracorporeal circulation. However. the hypotension is associated with a rapid reflex stimulation of the sympathoadrenal system, resulting in an exaggerated outpouring of epinephrine and norepinephrine into the circulation. Hence, one does not observe a significant dilutional effect of the pump priming volume on circulating catecholamines. Since enflurane and morphine do not cause inhibition of the sympathoadrenal system, ${ }^{8,9,13}$ the exaggerated sympathetic response is primarily responsible for maintenance of normotension (prebypass level).

In this study halothane was shown to suppress the adrenal epinephrine and norepinephrine output in relation to hypotension; hence the observed dilutional effect of priming volume on circulating epinephrine and norepinephrine.

Unless the associated hypotension is prolonged and does not respond to increasing the perfusion flow, the need for vaso-pressor support is rare. The question of whether reduced circulating catecholamine is of value to the cardiac patient is not presently known. It is unfortunate that we were not able to measure cardiac output in these patients. It is possible in certain patients that a reduction in peripheral resistance could be of value, particularly when there is a need to maintain microvasculature flow which may be compromised by cold and nonpulsatile bypass flow.

In summary, this study has demonstrated a transient period of hypotension at the start of cardiopulmonary bypass in aortocoronary bypass patients anaesthetized with halothane. The occurrence of circulating catecholamine dilution by the pump priming volume was found to be temporally associated with the hypotension. In contrast to patients anaesthetized with morphine or enflurane, recovery of the blood pressure to normotension with halothane anaesthesia is not due to stimulation of the sympatho-adrenal system but due to stimulation of another antihypotensive reflex mechanism, most likely renin-angiotension.

\section{ACKNOWLEDGEMENTS}

The authors gratefully acknowledge the technical assistance of Cathy Zurales, David Muller, Epperson Bond and Aaron Gary. 


\section{REFERENCES}

1. Boulanger, M. Levels of circulating norepinephrine and epincphrine before, during, and after cardiopulmonary bypass in man. Survey of Anesthesiology 21: 48 (1977)

2. Dunn, I., Kirsh. M.M., Harness, J. ef al Hemodynamic, metabolic, and hematologic effects of pulsatile cardio-pulmonary bypass. J. Thoracic Cardiovascular Surgery 68: 138 (1974).

3. Gordon, R.J., Ravin, M., Dalcoff, G.F., et al. Effects of hemodilution on hypotension during cardiopulmonary bypass. Anesthesia and Analgesia $54: 482$ (1975)

4. TAN, C.K., GlisSON, S.N., El-ETr. A.A. \& Younes, S.H. Adrenal responses to anesthetics during cardiopulmonary bypass. Cardiovascular Medicine 3: 521 (1978).

5. Balasaraswathi. K., Glisson, S.N., El-Etr, A.A. \& Pifarre, R. Serum epinephrine and norepinephrine during valve replacement and aortocoronary bypass. Canadian Anaesthetists' Society Journal 25: 198 (1978).

6. Branthwaite. M.A. Prevention of neurological damage during open-heart surgery. Thorax 30:258 (1975).

7. Branthwaite, M.A. Detection of neurological damage during open-heart surgery. Thorax 28: 464 (1973).

8. Stanley, T.H., Isern-Amarl, J. \& Lathrop,
G.D. The effects of morphine and halothane anaesthesia on urine norepinephrine during and after coronary àrtery surgery. Canad. Anaesth. Soc. J. 22: 478 (1975).

9. RoIzen, M.F., Moss. J., Henry. D.P. \& Kopin I.J. Effects of halothane on plasma catecholamines. Anesthesiology 41: 432 (1974).

10. Miller, E.D., Ackerly, J,A., VaughN. E.D. al. The renin-angiotension system during controlled hypotension with sodium nitroprusside. Anesthesiology 47: 257 (1977).

11. Bailey, D.R., Miller. E.D., Kaplan, J.A. et al. The renin-angiotension-aldosterone system during cardiac surgery with morphine-nitrous oxide anesthesia. Anesthesiology 42: 538 (1975).

12. TINKER, J.H. \& WHITE, R.D. Methylprednisolone and renin-angiotension mechanisms. Anesthesiology 43: 696 (1975).

13. Perry, L.D., Van Dyke, R.A. \& Theye, R.A. Sympathoadrenal and hemodynamic effects of isoflurane. halothane, and cyclopropane in dogs. Anesthesiology 40: 465 (1974).

14. Lowenstein, E., Hallowell, T. \& Levine. F.H. Cardiovascular response to large doses of intravenous morphine in man. New England Journal of Medicine 281: 1389 (1969).

15. Hasbrouck. J.D. Morphine anesthesia for openheart surgery. Annals of Thoracic Surgery 10: 364 (1970).

\section{RÉSUMÉ}

Plusieurs théories ont été proposées pour expliquer l'hypotension transitoire observée communément en début de circulation extracorporelle. Le présent travail avait pour but de vérifier l'hypothèse qui explique cette hypotension par la dilution des.catécholamines circulantes suite à l'emploi de Lactated Ringer comme liquide d'amorce de la pompe. A cette fin, on a mesuré les taux d'épinéphrine et de norépinéphrine durant la CEC chez des patients subissant un pontage aorto-coronarien sous anesthésie àl'halothane. On a trouvé de fait une dilution des catécholamines circulantes en début de CEC coincidant avec l'hypotension observée. La pression artérielle moyenne revenait graduellement à la normale en cours de CEC bien que les taux de catécholamines soient demeurés significativement abaissés, suggérant un mécanisme non adréno-sympathique.

Les résultats de notre étude indiquent donc une relation temporelle entre la dilution des catécholamines circulantes par le liquide d'amorce de la pompe de l'hypotension observée en début de CEC. Il reste à déterminer si ce facteur dilutionnel est le seul en cause ou si d'autres facteurs contribuent également au phénomène. 